[Tingkat Pengetahuan dan Pemahaman Wartawan Terhadap Kode Etik

Jurnalistik (Wartawan Kota Makassar)]

\title{
TINGKAT PENGETAHUAN DAN PEMAHAMAN WARTAWAN TERHADAP KODE ETIK JURNALISTK (WARTAWAN KOTA MAKASSAR)
}

\author{
Oleh :Harmin Hatta \\ Prodi Ilmu Komunikasi UIN Alauddin Makassar \\ Email : harmin.hatta@uin-alauddin.ac.id
}

\begin{abstract}
Abstrak
Penelitian ini bertujuan untuk mengetahui Tingkat Pengetahuan Wartawan Terhadap Kode Etik Jurnalistik. Kemudian, mengetahui Pemahaman Wartawan Terhadap Kode Etik Jurnalistik. Selain itu untuk mencari tahu Penerapan Pengetahuan dan Pemahaman Kode Etik Jurnalistik. Dalam penelitian ini digunakan metode penelitian kuantitatif-kualitatif konstruktif. Kemudian pengumpulan data yaitu: Observasi, interview, kuesioner, dokumentasi. Responden sekaligus sebagai Informan dalam penelitian ini adalah wartawan yang ada di Kota Makassar. Analisis data dalam pendekatan kualitatif-konstruktivis didahului oleh upaya mengungkap trustworthiness dari pada subjek penelitian. Trusworthiness ini diuji melalui pengujian: credibility subjek, autehenticity, Selanjutnya peneliti melakukan triangulation analisys serta reasoning yang logis. Tahapan berikutnya adalah melakukan intersubjectivity analisys. Hasil penelitian menunjukkan bahwa peranan Kode Etik Jurnalistik sangat di butuhkan oleh para insan Pers yang mencari berita di lapangan. Kode Etik Jurnalistik tentunya diharapkan akan menjadi bekal para wartawan untuk menekuni sebuah profesi jurnalistik sehingga mereka dapat bekerja dengan baik dan benar. Kemudian upaya-upaya yang dilakukan oleh para wartawan dalam menekuni profesi ini sehingga mereka dapat melaksanakan, menyelesaikan tugas dan tanggung jawabnya sebagai wartawan yang profesional. Implementasi penelitian ini, ada beberapa hal yang menjadi harapan penulis sehubungan dengan Tingkat Pengetahuan Wartawan Terhadap, Kode Etik Jurnalistik Wartawan Kota Makassar, yaitu sebagai berikut :1). Kinerja wartawan hari ini lebih ditingkatkan lagi dalam mencari dan menerbitkan sebuah berita dan lebih mengedepankan nilai-nilai etika dan menjunjung tinggi Kode Etik Jurnalistrik sesuai dengan fakta yang terjadi dilapangan. 2). Tidak menyalah gunakan profesinya sebagai wartawan seperti, memeras narasumber yang dianggap punya masalah dengan hukum. 3). Lebih serius dalam menjalankan tugas sebagai wartawan, tentang apa yang mereka ketahui, pahami dan menjalankannya sesuai dengan aturan-aturan yang telah ditetapkan oleh Dewan Pers pada tanggal 14 Maret Tahun 2006.
\end{abstract}




\section{A. PENDAHULUAN}

Pers adalah salah satu wahana komunikasi massa yang melaksanakan kegiatan jurnalistik meliputi mencari, memperoleh, memiliki, meminjam, mengolah, menyampaikan informasi baik dalam bentuk tulisan, suara dan gambar, serta data dan grafik maupun dalam bentuk lainya dengan menggunakan media cetak, media eletronik dan media online.

Oleh karena diperlukan suatu kode etik bagi seorang jurnalis sebagai pedoman serta pegangan, karena etika merupakan sesuatu yang lahir dan keluar dari hati nurani seseorang, yang sangat diharapkan dapat mendorong serta memberi pengaruh positif dalam menjalankan tugas serta tanggung jawab sesuai profesi yang dijalankan. ${ }^{1}$

Keberadaan dan pelaksanaan Kode Etik Jurnalistik sebagai norma atau disebut landasan moral profesi wartawan dikaitkan dengan nilai-nilai yang merupakan kaidah penentu bagi para jurnalis dalam melaksanakan tugasnya, sekaligus memberi arah tentang apa yang seharusnya dilakukan serta yang seharusnya ditinggalkan. Namun demikian,tidak dapat dipungkiri bahwa dalam praktek sehari-hari masih terdapat (tidak semuanya) berbagai penyimpangan-penyimpangan terhadap kode etik jurnalistik maupun terhadap ketentuanketentuan lain (norma-norma hukum) yang berlaku bagi profesi ini. Hal ini barangkali dapat dimakluni, sebab mereka yang berkecimpung didalam dunia jurnalistik adalah manusia. Sama halnya dengan profesi lainnya. ${ }^{2}$

Setiap kebebasan termasuk pers sendiri tentunya mempunyai batasan, dimana batasan yang paling utama dan tak pernah salah adalah apa yang keluar dari hati nuraninya. Dalam hal ini, kebebasan pers bukan saja dibatasi oleh kode etik jurnalistiknya akan tetapi tetap ada

\footnotetext{
${ }^{1}$ Budayatna Muhammad. Teori dan Praktik Jurnalistik. Cet. I; Bandung: PT REMAJA ROSDAKARYA, 2005.

${ }^{2}$ Media Indonesia. Jurnalisme Infotaiment Abaikan Etika Jurnalistik.Jakarta : Selasa 30 agustus 2005. (Diakses 27 November 2017).
} 
batasan lain, misalnya ketentuan menurut Undang-undang. Pada prinsipnya menurut Undang-Undang No. 40 Tahun 1999 menganggap bahwa kegiatan jurnalistik/kewartawanan merupakan kegiatan/usaha yang sah yang berhubungan dengan pengumpulan, pengadaan dan penyiaran dalam bentuk fakta, pendapat atau ulasan, gambar-gambar dan sebagainya, untuk perusahaan pers, radio, televisi dan film. Guna mewujudkan hal tersebut dan kaitannya dengan kinerja dari pers. Keberadaan insan-insan pers yang profesional tentu sangat dibutuhkan, sebab walau bagaimanapun semua tidak terlepas dari insan-insan pers itu sendiri. Olehnya, seorang wartawan yang baik dan profesional sedapat mungkin memiliki syaratsyarat, yaitu: bersemangat, agresif, prakarsa, berkeperibadian, mempunyai rasa ingin tahu, jujur, bertanggungjawab, akurat, tepat, pendidikan yang baik, dan mempunyai kemampuan menulis dan berbicara yang baik.

Seorang wartawan hendaknya menempuh jalan dengan cara yang jujur untuk memperoleh bahan-bahan berita dan tulisan, dengan meneliti kebenaran dan akurasinya sebelum menyiarkannya serta harus memperhatikan kredibilitas sumbernya. Di dalam menyusun suatu berita hendaknya dibedakan antara kejadian (Fakta) dan Pendapat (opini) sehingga tidak mencampur baurkan antara keduanya termasuk di dalamnya adalah objektifitas dan sportifitas berdasarkan kebebasan yang bertanggung jawab, serta menghindari cara-cara pemberitaan yang dapat menyinggung peribadi seseorang, sensasional, inmoral dan melanggar kesusilaan.

Penyiaran suatu berita yang berisi tuduhan yang tidak berdasar, desas-desus, hasutan yang dapat membahayakan bangsa dan Negara, fitnahan, pemutar balikan suatu kejadian adalah merupakan pelanggaran berat terhadap profesi jurnalistik. 
Menanggapi besarnya keselamatan yang dapat ditimbulkan dari proses/cara pemberitaan serta menyatakan pendapat diatas, maka dalam kode etik jurnalistik diatur juga mengenai hak jawab dan hak koreksi, dalam artian bahwa pemberitaan/penulisan yang tidak benar harus ditulis dan diralat kembali atas keinsafan wartawan yang besangkutan, dan pihak yang merasa dirugikan wajib diberi kesempatan untuk menjawab dan memperbaiki pemberitaan dimaksud.

Masyarakat sudah lama sangat terganggu dengan keberadaan wartawan gadungan, wartawan amplop, atau wartawan bodrex, yakni orang yang mengaku wartawan atau benar wartawan namun menyalahgunakan profesinya dengan tujuan mencari duit.

Selain itu, kalangan media juga harus terus melakukan pembinaan internal untuk meningkatkan profesionalisme wartawannya, utamanya dalam hal ketaatan pada kode etik jurnalistik. Poin 5 Kode Etik Wartawan Indonesia (KEWI) yang ditetapkan Dewan Pers (SK No. 1/ SK-DP/2000 tanggal 20 juni 2000) menyebutkan," Wartawan Indonesia tidak menerima suap dan menyalahgunakan profesi". Kita sangat "angkat topi" bagi sejumlah media massa yang mengharamkan wartawan menerima amplop, karena memang itu tidak perlu. Isi amplop hanya akan membebani sang wartawan untuk menurunkan berita, padahal dimuat-tidaknya sebuah berita bukan wewenangnya, melainkan merupakan wewenang redaktur yang menjadi atasannya. Lain soal jika sang redaktur "kecipratan" dan turut punya beban moral.

"Budaya amplop" juga mengurangi profesionalisme para wartawan, termasuk bobot berita.Berita adalah laporan peristiwa. Namun tidak semua peristiwa layak dilaporkan (dijadikan berita). 
Sebuah peristiwa layak diberitakan (fit to print) hanya jika mengandung nilai-nilai jurnalistik atau news value, seperti aktual, faktual, penting, dan menarik.

Sebuah amlop dapat membuat wartawan menjalankan tugasnya secara tidak fair, berat sebelah, biasa, hanya menguntungkan satu pihak. Sedangkan wartawan profesional menulis berita secara seimbang (balanced), cover both side, memegang Fairness Doctrine (doktrin kejujuran). Jika demikian pembaca atau masyrakat yang dirugikan karena tidak mendapatkan informasi yang utuh dan berimbang.

Entah siapa yang memulai, wartawan yang minta duit ataukah panitia yang menyuap wartawan, sehingga terbentuk "budaya amlop"itu.Yang jelas, kebiasaan buruk itu harus segera dihentikan sekarang juga.Jika ada acara bagus dan layak diberitakan, wartawan akan datang dengan sendirinya, bahkan tidak diundang sekalipun. Panitia acara cukup mengirimkan pemberitahuan atau menulis (press realease).

Dalam sebuah acara di Jakarta, sebagaimana dipulikasikan www.dewanpers.org, Sekretaris Jendral Aliansi Jurnalistik Indonesia, (waktu itu) Didik suprianto, mengusulkan agar kalangan kehumasan tidak mengorganisir wartawan, seperti yang dilakukan berbagai institusi dan perusahaan, sehinga tidak akan ada lagi istilah "wartawan Polda", "wartawan Pertamina”, “wartawan Kejaksaan”, dan sebagainya. Langkah tersebut diperlukan untuk menekan penyalahgunaan profesi wartawan untuk mencari uang dari sumber berita.

Etika jurnalistik adalah barang langka yang acapkali disusun dengan susah payah, tapi begitu jadi segera dilupakan. Paling tidak, menurut pengetahuan penulis, tidak ada seorang wartawan pun di Indonesia ini yang pernah menuliskan pengalaman mereka mengenai bagaimana praktek beretika selama menjadi wartawan. Para wartawan di Indonesia lebih suka menulis studi kasus, atau memoar, atau panduan praktis untuk meliput. Kalau pun buku etika jurnalistik lebih banyak ditulis oleh kalangan akademisi. Penulis tak tahu apakah hal ini 
disebabkan para wartawan Indonesia tak tertarik pada persoalan etika, atau memang etika jurnalistik adalah sebuah barang yang asing bagi mereka. ${ }^{3}$

\section{B. Bahan dan Metode}

\section{Desain Penelitian}

Penelitian ini dilaksanakan dalam wilayah Makassar. Sebab daerah ini mempunyai komposisi Pers/Wartawan yang heterogen. Makassar diasumsikan sebagai daerah yang memiliki perkembangan yang tinggi. Makassar sebagai ibu kota dinilai sebagai acuan kondisi sosial di Sulawesi Selatan. Selain itu ketersediaan media massa yang cukup. Waktu penelitian di mulai sejak bulan September sampai dengan bulan November 2018.

\section{Populasi dan Sampel}

Populasi dalam penelitian ini adalah seluruh wartawan yang ada di Kota Makassar. Sampel adalah sebagian dari keseluruhan objek atau fenomena yang akan diamati. Dimana populasi dan sampel yang akan dijadikan sebagai objek penelitian adalah pers/wartawan yang ada di Makassar baik yang aktif di media cetak, media penyiaran seperti TV dan Radio maupun yang ada di media Online.

Dari populasi tersebut di tentukan jumlah sampel dengan Nonprobality sampel untuk melihat tingkat pengetahuan dan pemahaman wartawan terhadap Kode Etik Jurnalistik, wartawan Kota Makassar tanpa diwakilkan oleh orang lain sehingga responden dapat memberikan tanggapan secara objektif. Dengan teknik ini maka jumlah sampel yang didapatkan oleh peneliti adalah 20 orang.

\section{Metode Pengumpulan Data}

Penelitian ini menggunakan beberapa metode untuk penunjang penelitian, antara lain: Observasi (pengamatan) adalah suatu teknik penelitian yang digunakan oleh peneliti dengan jalan turun langsung ke lapangan mengamati objek secara langsung guna mendapatkan data yang lebih jelas. Yaitu pengamatan dan pencatatan secara sistematis terhadap gejala-gejala yang tampak pada objek penelitian. ${ }^{4}$

\footnotetext{
${ }^{3}$ Budi Prayitno (Penerj.), Etika Jurnalisme: Debat Global. Cet. I; (Jakarta: Institut Studi Arus Informasi \& Kedutaan Besar Amerika Serikat, 2003), h. xviii

${ }^{4}$ Arikunto Suharsimi. Prosedur Penelitian Suatu Pendekatan Praktek, Jakarta : PT.Rineka Cipta. 2007, Cet XII. h 109.
} 
Interview (Wawancara), yaitu proses tanya jawab dalam penelitian yang berlangsung secara lisan dimana dua orang atau lebih bertatap muka mendengarkan secara langsung informasi-informasi atau keterangan-keterangan secara mendalm dan detail. Bertemunya dua orang untuk bertukar informasi dan ide melalui Tanya jawab, sehingga dapat konstruksikan makna dalam suatu data tertentu, wawancara digunakan sebagai teknik pengumpulan data apabila peneliti ingn melakukan studi pendahuluan untuk menemukan permasalahan yang harus diteliti dan dan ingin mengetahui hal-hal yang paling dalam. ${ }^{5}$

Dokumentasi adalah pengumpulan bukti dan keterangan seperti foto, kutipan materi dan berbagai bahan referensi lain yang berada dilokasi penelitian dan dibutuhkan untuk memperoleh data yang valid. Merupakan catatan peristiwa yang telah berlalu, berupa tulisan, gambaran atau karya-karya monumental. Studi dokumen merupakan pelengkap dari penggunaan metode observasi dan wawancara dalam penelitian kualitatif. Hasil penelitian dari observasi dan wawancara dapat dipercaya jika didukung oleh riwayat hidup atau sejarah berdiri sebuah lembaga serta didukung oleh beberapa foto yang telah ada. ${ }^{6}$

Kuesioner, yaitu pengumpulan data yang dilakukan dengan menggunakan daftar pertanyaan yang berkenaan dengan aspek-aspek Kode Etik Jurnalistik.

\section{Analisis Data}

Analisis data dalam pendekatan kualitatif-konstruktivis didahului oleh upaya mengungkap trustworthiness dari pada subjek penelitian. Yaitu menguji kebenaran dan kejujuran subjek penelitian dalam mengunkap realitas. Trusworthiness ini diuji melalui pengujian: credibility subjek, dengan menguji jawaban-jawaban pertanyaan berkaitan dengan pengalaman pengetahuan mereka yang khas. Berikutnya adalah menguji autehenticity, yaitu peneliti memberi kesempatan dan memfasilitasi pengungkapan konstruksi yang lebih detail. Selanjutnya peneliti melakukan triangulation analisys, yaitu menganalisis jawaban subjek penelitian dengan meneliti autentitasnya berdasar data empiris yang ada. Peneliti menjadi fasilitator untuk menguji keabsahan setiap jawaban berdasarkan dokumen atau data lain, serta reasoning yang logis. Tahapan berikutnya adalah melakukan intersubjectivity analisis. Artinya semua pandangan, pendapat ataupun data dari suatu subjek penelitian, didialogkan dengan pendapat, ataupun data dari subjek lainya.

\footnotetext{
${ }^{5}$ Lexy Moleong Johannes. Metodologi Penelitian Kualitatif, Bandung, Remaja Rosdakarya, 2002), h 146.

${ }^{6}$ Sugiyono. Metode Penelitian Kualitatif, Jakarta, Rajawali : 2000, h 82-83.
} 
Hasil dari wawancara ini kemudian dianalisis dan diinterpretasi dengan menggunakan kategori-kategori analisis (filling system).

\section{HASIL}

\section{Karakteristik Responden}

Berdasarkan tabel 1, menunjukkan bahwa responden didominasi oleh yang berumur 20-30 tahun. Hal ini dimungkinkan karena kelompok usia ini sangat mudah dan termasuk kategori usia produktif sehingga masih punya semangat yang tinggi dalam menggeluti profesi kewartawanan.

Berdasarkan tabel 2 klasifikasi perbedaan responden pada Tabel 4.2 di atas bahwa pria lebih banyak berprofesi sebagai wartawan $(85,0 \%)$ dibanding wanita $(15,0 \%)$. Hal ini dimungkinkan karena pria sebagai kepala rumah tangga dan lebih besar tangggung jawabnya.

Berdasarkan tabel 3 identifikasi pendidikan menggambarkan bahwa tingkat pendidikan responden baik, dimana responden yang berpendidikan SD dan SLTP (0\%), SLTA (20\%), Sarjana /S1, Master/S2, Doktor/S3 (80\%).

Dimana responden yang berpendidikan tinggi ke atas (80\%). Dengan tingkat pendidikan demikian, maka responden yang terjaring kiranya dapat memberikan respon yang kritis dan objektif terhadap pengetahuan dan pemahaman Kode Etik Jurnalistik.

Berdasarkan tabel 4 identifikasi responden dapat juga dilihat dari segi organisasi yang digelutinya. Pada tabel tersebut dari responden dapat di klasifikasi organisasi yang digelutinya berdasarkan keinginan responden. Klasifikasi perbedaan organisasi tebagi atas 5 (lima) kategori, yaitu PWI (40\%), AJI (30\%), PWNI (5\%), PJI (5\%) dan Lain-lain atau responden yang tidak masuki dalam organisasi sebanyak (20\%).

Identifikasi responden berdasarkan instrumen media dapat di lihat pada tabel 5 tersebut. Dapat dijelaskan sebagai berikut: untuk kategori media cetak tedapat (60\%), untuk media eletronik (20\%), dan kategori media online sebanyak (20\%). Ini menandakan bahwa responden lebih didominasi oleh media cetak. 


\section{PEMBAHASAN}

Penelitian ini secara umum menyangkut tanggapan dan jawaban wartawan terhadap Kode Etik Jurnalistik. Tanggapan identik dengan kesan yang tinggal, dalam ingatan setelah melakukan pengamatan terhadap suatu objek. Dalam proses terbentuknya suatu tanggapan dipengaruhi oleh sejumlah faktor, diantaranya faktor kebutuhan, sifat, kepercayaan dan bidang pengalaman. Faktor-faktor tersebut terakumulasi dalam perasaan dan penalaran seseorang yang kemudian membentuk kerangka acuan. Kerangka acuan itulah yang pada akhirnya akan mempengaruhi bagaimana seseorang menaggapi stimulus yang diterimanya.

Secara operasional, tanggapan dalam penelitian ini didefinisikan sebagai pernyataan subjektif yang diberikan oleh masyarakat terhadap tingkat pengetahuan dan pemahaman wartawan, terhadap Kode Etik Jurnalistik.

Berdasarkan data yang telah diperoleh, terungkap dalam analisa deskriptif bahwa berdasarkan klasifikasi perbedaan umur responden. Responden terbanyak adalah kelompok usia produktif antara 20-30 tahun sebanyak 10 responden (50\%), kelompok 31-40 tahun sebanyak 7 responden (35\%), kemudian 41-50 tahun sebanyak 3 responden (15\%), dan kelompok usia > 50 tahun menempati posisi keempat dan tidak ada respondennya.

Berdasarkan klasifikasi perbedaan jenis kelamin, terdapat 17 responden $(85 \%)$ berjenis kelamin pria dan 3 orang responden (15\%) yang berjenis kelamin wanita.

Berdasarkan klasifikasi tingkat pendidikan responden dengan tingkat pendidikan terbanyak adalah sarjana S1 sebanyak 17 responden (85\%) kemudian tamat SLTA/SMA sebanyak 2 responden (10\%), dan Sarjana Muda/Diplooma 1 responden (5\%).

Berdasarkan klasifikasi organisasi yang digeluti oleh responden, dengan organisasi terbanyak digeluti oleh responden adalah Persatuan Wartawan Indonesia (PWI) sebanyak 8 responden (40\%), Aliansi Wartawan Independen (AJI) sebanyak 6 responden (30\%), Lainlain (responden yang tidak masuk di organisasi) sebanyak 4 responden (20\%), kemudian Persatuan Wartawan Nasional Indonesia (PWNI) sebanyak 1 responden (5\%), dan Perhimpunan Jurnalis Indonesia (PJI) sebanyak 1 responden (5\%).

Berdasarkan klasifikasi instrumen media menurut profesi yang digeluti oleh responden, dengan media terbanyak adalah media cetak sebanyak 12 responden (60\%), kemudian media eletronik sebanyak 4 responden (20\%), dan media Online sebanyak 4 responden $(20 \%)$. 
Wartawan yang ada di Kota Makassar mengetahui tentang Kode Etik Jurnalistik yang ada sekarang. Wartawan sebagai profesi selalu menggunakan kode etik sebagai acuan dalam menjalankan tugasnya sebagai abdi Negara dalam mencari, memburu, menulis sampai berita diturunkan.

Berdasarkan apa yang menjadi sebuah tuntutan untuk menjalankan sebuah profesi yang selalu dilandasi dengan sikap tanggungjawab terhadap apa yang dilakukan. Kode Etik Jurnalistik sebaiknya tetap menjadi pedoman dan petunjuk para insan pers dalam melaksanakan tugas dan fungsi wartawan sebagai corong dalam menyiarkan sebuah peristiwa yang terjadi dilapangan dan tetap berpihak pada nilai-nilai kebenaran.

Penekanan tanggung jawab moral kepada masyarakat dengan usaha untuk menghindari kemungkinan terjadinya keadaan yang membahayakan kesejahteraan umum. Dalam teori tanggungjawab sosial ini berasal dari sebagian besar laporan "Komisi Hutchins" yang diterbitkan pada tahun 1947. Dari laporan ini dikembangkan pendapat betapa pentingnya peran pers dalam masyarakat modern seperti sekarang ini, menekankan pada keharusan akan adanya tanggung jawab sosial dari setiap pers komunikasi.

Para pemilik pers pada teori tanggung jawab sosial yang tidak puas terhadap fungsi pers dalam teori libertarian, berpendapat bahwa pers tidak dapat menjalankan fungsinya secara sempurna. Dalam memberikan pelayanan kepada sistem ekonomi, mereka mengharapkan agar tugas-tugas yang dijalankan oleh pers tidak mendahului fungsi-fungsi pers yang lain, seperti meningkatkan proses demokrasi dan pemberian penerangan kepada masyarakat. Hiburan yang disajikan haruslah hiburan yang baik. Dalam mencukupi keuangan pers-pers individu tertentu, hendaknya diberikan kebebasan untuk mencari pasar.

Keberadaan dan pelaksanaan Kode Etik Jurnalistik sebagai norma atau disebut landasan moral profesi wartawan dikaitkan dengan nilai-nilai yang merupakan kaidah penentu bagi para jurnalis dalam melaksanakan tugasnya, sekaligus memberi arah tentang apa yang seharusnya dilakukan serta yang seharusnya ditinggalkan. Namun demikian, tidak dapat dipungkiri bahwa dalam praktek sehari-hari masih terdapat (tidak semuanya) berbagai penyimpangan-penyimpangan terhadap Kode Etik Jurnalistik maupun terhadap ketentuan-ketentuan lain (norma-norma hukum) yang berlaku bagi profesi ini. Hal ini barangkali dapat dimaklumi, sebab mereka yang berkecimpung di dalam dunia jurnalistik adalah manusia. Sama halnya dengan profesi lainnya. 
Demikian pula bahwa terkadang suatu keadaan dan kondisi tertentu ikut pengaruhi banyak hal di dalam bidang ini, sehingga mungkin saja memunculkan suatu pemikiran, bahwa diperlukan adanya perubahan-perubahan di dalam kode etik itu sendiri atau kesadaran manusianya yang perlu ditingkatkan. Kode etik merupakan prinsip yang keluar dari hati nurani setiap profesi tentulah membutuhkan patokan moral dalam profesinya.

Sebagian wartawan tidak memahami Kode Etik Jurnalistik, bahkan lebih lanjut menyebutkan bahwa ada oknum wartawan yang masih tidak menaati Kode Etik Jurnalistik dan melakukan pelanggaran keras, seperti pemerasan yang dilakukan pada saat melakukan liputan. Dari uraian dijelaskan bahwa penyebab wartawan melakukan praktek pelanggaran kode etik karena masih banyak media yang memberikan gaji sedikit kepada wartawan, sehingga para wartawan tanpa mempertimbangkan apa yang telah dilakukan dalam hal ini mengambil amplop yang disodorkan ketika selesai mewawacari narasumbernya.

Penerapan Kode Etik Jurnalistik yang merupakan gambaran serta arah, apa dan bagaimana seharusnya profesi ini dalam bentuk idealnya oleh sebagian pers atau media massa belum direalisasikan sebagaimana yang diharapkan, yang menimbulkan kesan bahwa dunia jurnalistik (juga profesi lain) terkadang memandang kode etik sebagai pajanganpajangan yang kaku. Namun terlepas dari ketimpangan dari apa yang seharusnya bagi dunia jurnalistik tersebut, tampaknya hal ini berpulang pada persepsi dan obyektifitas masyarakat/publik untuk menilai kualitas, bobot, popularitas maupun keberpihakan dari suatu media massa.

Kebebasan pers yang banyak didengungkan, sebenarnya tidak hanya dibatasi oleh Kode Etik Jurnalistik, tetapi terdapat aturan lain yang dapat dipergunakan untuk mewujudkan apa yang seharusnya. Untuk itulah masih diperlukan langkah-langkah konkrit dalam rangka mewujudkan peran dan fungsi pers, paling tidak menutup kemungkinan untuk dikurangi dari penyimpangan tersebut.

Berbicara masalah etika, khususnya dalam profesi jurnalistik (wartawan) sangatlah menghadapi tantangan yang besar terlebih dalam era globalisasi. Dari satu sisi, kemajuan dan perubahan teknologi mendorong perubahan nilai-nila moral dan etika, dengan demikian makin kompleksnya masyarakat makin banyak dilema moral yang harus dipertimbangkan, di sisi lain hal ini menjadikan semakin sulitnya untuk menimbang secara jernih apa yang etis 
serta apa yang tidak etis. Hal ini paling tidak menjadikan etika sulit ditegakkan, meski etika juga semakin penting untuk menjaga kepentingan profesi.

Media sebagai corong informasi publik yang sehat dan mendidik serta punya fungsi kontrol yang jelas harus tetap mengedepankan nilai-nilai sosial yang berdampak pada tahap pembangunan karakter masyarakat yang lebih baik kearah kemajuan dengan tetap mendapatkan informasi melalui media cetak maupun media elektronik seperti televisi, radio dan media online. Sekarang kita banyak menyaksikan fungsi media yang tidak lagi mengedepankan nilai-nilai sosial seperti edukasi kepada masyarakat dan kontrol terhadap pemerintah, sudah mulai ada pergeseran dan cenderung mengejar profit atau keuntungan semata. Latar belakang pendidikan wartawan bisa dikatakan berpengaruh bisa juga tidak, karena kondisi saat ini justru terkadang yang pernah kuliah di jurusan jurnalistik tidak bisa mengimplementasikan ilmunya saat menjalankan tugaskewartawanan, sementara yang berasal dari jurusan lain mereka cenderung lebih baik karena mereka tekun mendalami tentang tugas pokok pers dan Kode Etik Jurnalistik, serta mampu menjalankan profesi jurnalis dengan benar. Wartawan profesional harus tetap meliput dan mengirim ke redaksi perusahaan media. Tapi yang perlu dipahami, wartawan bukanlah penentu naik tidaknya suatu berita tetapi redaktur yang menentukan. Kehadiran dewan pers saat ini dianggap sudah efektif dalam melaksanakan penerapan Kode Etik Jurnalistik, namun tetap menuai banyak kritik dari masyarakat yang menganggap belum maksimal kinerja dewan pers dalam menindak oknum wartawan yang melakukan praktek pelanggaran kode etik, seperti menerima suap saat liputan. Dewan pers saat ini sudah berupaya menangani permasalahan pers, dewan pers juga melakukan pencegahan pelanggaran kode etik bagi wartawan, salah satunya mendorong perusahaan media agar pemimpin redaksi, redaktur, dan wartawannya harus ikut uji kompetensi wartawan (UKW).

Keberadaan dan pelaksanaan Kode Etik Jurnalistik sebagai norma atau disebut landasan moral profesi wartawan dikaitkan dengan nilai-nilai pancasila, oleh karena Kode Etik Jurnalistik merupakan kaidah penentu bagi para jurnalis dalam melaksanakan tugasnya, sekaligus memberi arah tentang apa yang seharusnya dilakukan serta yang seharusnya ditinggalkan. Namun walau demikian,tidak dapat dipungkiri bahwa dalam praktek sehari-hari masih terdapat (tidak semuanya) berbagai penyimpangan-penyimpangan terhadap Kode Etik 
Jurnalistik maupun terhadap ketentuan lain (norma-norma hukum) yang berlaku bagi profesi ini.

Komisi yang selanjutnya terkenal dengan sebutan Hutchins Commission ini mengajukan 5 prasyarat sebagai syarat bagi pers yang bertanggungjawab kepada masyarakat. Lima prasyarat tersebut adalah:

1. Media harus menyajikan berita-berita peristiwa sehari-hari yang dapat dipercaya, lengkap, dan cerdas dalam konteks yang memberikannya makna. (Media harus akurat; mereka tidak boleh bohong, harus memisahkan antara fakta dan opini, harus melaporkan dengan cara yang memberikan arti secara internasional, dan harus lebih dalam dari sekedar menyajikan fakta-fakta dan harus melaporkan kebenarannya).

2. Media harus berfungsi sebagai forum untuk pertukaran komentar dan kritik. (Media harus menjadi sarana umum; harus memuat gagasan-gagasan yang bertentangan dengan gagasan-gagasan sendiri, "sebagai dasar pelaporan yang objektif"; semua "pandangan dan kepentingan yang terpenting" dalam masyarakat harus diwakili; media harus mengidentifikasi sumber informasi mereka karena hal ini "perlu bagi sebuah masyarakat yang bebas."

3. Media harus memproyeksikan gambaran yang benar-benar mewakili dari kelompokkelompok konstituen dalam masyarakat. (Ketika gambaran-gambaran yang disajikan media gagal menyajikan suatu kelompok sosial , maka pendapat disesatkan; kebenaran tentang kelompok mana pun harus benar-benar mewakili; ia harus mencakup nilai-nilai dan aspirasi-aspirasi kelompok, tetapi ia tidak boleh mengecualikan kelemahankelemahan dan sifat-sifat buruk kelompok).

4. Media harus menyajikan dan menjelaskan tujuan-tujuan dan nilai-nilai masyarakat. (Media adalah instrument pendidikan mereka harus memikul suatu tanggungjawab untuk menyatakan dan menjelaskan cita-cita yang diperjuangkan oleh masyarakat).

5. Media harus menyediakan akses penuh terhadap informasi-informasi yang tersembunyi pada suatu saat. (Ada kebutuhan untuk "pendistribusian berita dan opini secara luas") ${ }^{7}$.

\footnotetext{
${ }^{7}$ Hikmat Kusumaningrat dan Purnama Kusumaningrat. Jurnalistik Teori dan Praktik, Bandung PT Remaja
} Rosdakarya. 2006, Cet 2. h 21-22. 


\section{E. KESIMPULAN}

Berdasarkan hasil penelitian dan pembahasan yang telah di kemukakan pada bab-bab sebelumnya mengenai tanggapan wartawan tentang tingkat pengetahuan dan pemahaman terhadap Kode Etik Jurnalistik dapat di tarik kesimpulan.

1. Dari hasil analisis dan pembahasan dapat disimpulkan bahwa sebagian besar wartawan mengetahui bahkan pernah membaca tentang Kode Etik Jurnalistik.

2. Dari hasil analisis dan pembahasan dapat disimpulkan bahwa secara umum wartawan yang ada di Kota Makassar sudah memahami tentang Kode Etik Jurnalistik.

3. Sesuai dengan hasil analisis dan temuan dilapangan dapat disimpulkan bahwa masih banyak wartawan yang belum mengedepankan Kode Etik Jurnalistik dalam menjalankan tugas dan tanggungjawabnya sebagai insan Pers yang profesional. Media massa saat ini berada pada tiga kepentingan. Pertama, masih ada yang menyajikan informasi benarbenar untuk kepentingan publik yang senantiasa didasarkan pada prinsip dasar Kode Etik Jurnalistik dan Kode Etik Perilaku. Kedua, ada yang terjebak pada kepentingan politik praktis didasarkan pada pemilik media itu sendiri. Ketiga, ada media massa terjebak murni pada kepenting 


\section{DAFTAR PUSTAKA}

Budayatna, Muhammad. Teori dan Praktik Jurnalistik. Cet. I; Bandung: PT REMAJA ROSDAKARYA, 2005.

Budi Prayitno (Penerj.), Etika Jurnalisme: Debat Global. Cet. I; (Jakarta: Institut Studi Arus Informasi \& Kedutaan Besar Amerika Serikat, 2003), h. xviii.

Dekdikbud. Kamus Bhs Indonesi, Cet I. hal 102; Jakarta : PT Balai Pustaka, 1984.

Hikmat Kusumaningrat dan Purnama Kusumaningrat. Jurnalistik Teori dan Praktik, Bandung PT Remaja Rosdakarya. 2006, Cet 2. h 21-22.

Media Indonesia. Jurnalisme Infotaiment Abaikan Etika Jurnalistik.Jakarta : Selasa 30 agustus 2005.(Diakses 27 November 2009).

Moleong, Lexy Johannes. Metodologi Penelitian Kualitatif, Bandung, Remaja Rosdakarya, 2002), h 146.

Sugiyono. Metode Penelitian Kualitatif, Jakarta, Rajawali : 2000, h 82-83.

Suharsimi, Arikunto. Prosedur Penelitian Suatu Pendekatan Praktek, Cet.XII. hal 109 Jakarta : PT.Rineka Cipta. 2007.

Sukardi Wina Armada, Cara Mudah Memahami Kode Etik Jurnalistik Dan Dewan Pers. Cet. I, Jakarta: Perpustakaan Nasional RI: Katalog Dalam Terbitan, 2008.

Sobur, Alex. Etika Pers; Profesionalisme dengan Nurani, Bandung: PT Remaja Rosda Karya, 2001 